КУЛЬТУРОЛОГИЧЕСКИЕ ИССЛЕДОВАНИЯ

УДК [281.96(571.15)(=161.1):39]:069.1

DOI: $10.32340 / 2414-9101-2021-2-7-12$

И. В. Куприянова, доктор исторических наук, доцент Алтайский государственный институт культуры (Барнаул, Россия)

irinak-63@mail.ru

\title{
ПРОБЛЕМЫ МУЗЕЕФИКАЦИИ НАСЛЕДИЯ СТАРООБРЯДЧЕСКОЙ КУЛЬТУРЫ НА АЛТАЕ
}

\begin{abstract}
Аннотация. Рассмотрены возможности интеграции историко-культурного наследия старообрядчества Алтая (юг Западной Сибири, Россия) в современное музейное пространство региона. Автор выделяет структурные компоненты наследия старообрядчества, даёт оценку их сохранности и степени изученности. Проанализированы актуальные проблемы атрибуции старообрядческого наследия, его включения в действующие музейно-туристические программы. Приоритетным направлением разработки старообрядческого наследия, на взгляд автора, является выявление и переосмысление его информационного наполнения, широкого привлечения устно-исторических и фольклорно-этнографических источников, с помощью которых возможно компенсировать дефицит материальных артефактов.

Ключевые слова: старообрядчество, историко-культурное наследие, историко-культурное наследие алтайского старообрядчества, семиотический дискурс, музейный продукт, культурный ландиафт, туризм.
\end{abstract}

Актуальность темы заключается в недостаточной на сегодняшний день представленности культуры старообрядчества в музейно-выставочной практике. Такое положение вещей не отражает масштабов этой исторической цивилизационной общности, ее места в истории и культуре России, и, кроме того, не соответствует ее вкладу в культурно-хозяйственное освоение окраин страны. Такое положение вещей сложилось не только в региональных и местных музеях, но и в крупных фондохранилищах России и зарубежья, где фиксируется большое количество ошибок при атрибуции памятников старообрядческой культуры [1, с. 52]. В целом, эта работа еще только начинается, хотя некоторые сдвиги уже имеются; так, например, в музеях Московской области, в исторических центрах старообрядчества работают проекты по презентации его культуры, преимущественно в религиозном компоненте [2, с. 32].

Проблеме музеефикации культурного наследия старообрядчества в настоящее время уделяется большое внимание исследователей. Здесь можно выделить несколько принципиальных позиций. Одна из них заключается в признании факта несомненной ценности этого наследия, тесно связанного с культурой Древней Руси. При этом, однако, древнерусское наследие старообрядчества часто рассматривается в аспекте коллекционирования и меценатства, формирования коллекций древнерусского искусства богатыми старообрядцами-предпринимателями дореволюционной России и соответствующих собраний в музеях в современный период [1, с. 53]. В музейной презентации старообрядческого наследия акцент ставится на деятельности старообрядческих художественных мастерских по производству предметов культа, прежде всего книг и икон, в том числе медной 
литой пластики, принимаемой старообрядцами, а также на показе священнического облачения, интерьеров музеефицированных культовых зданий [2].

Признавая важность данного направления, следует отметить, что понятие культурного наследия старообрядчества несводимо только к богословской книжности и произведениям религиозного искусства: оно включает в себя материальные памятники социально-экономической деятельности старообрядчества, а главное - весь комплекс материальной и духовной народной культуры. Это объясняется тем, что старообрядчество - не просто религиозное направление в православном христианстве: оно представляет его самобытный великорусский этнонациональный вариант. Следовательно, очевидна его неразрывная связь с этнической культурой, включая ее дохристианский пласт. В этом качестве оно и должно продвигаться в культурно-познавательных программах.

В массиве культурного наследия старообрядчества можно выделить три основных компонента: во-первых, культурный ландшафт, представляющий собой недвижимые объекты - памятники архитектуры, коммуникации, природные объекты; во-вторых, музейные собрания - вещевые коллекции, фото- и видеоматериалы, документы; в-третьих, фольклорно-этнографические памятники, представляющие нематериальное наследие. Все три компонента могут презентоваться как в комплексе, так и отдельно, в виде обзорных экскурсий, экспозиций и выставок, фольклорных программ, лекций, мастер-классов.

На Алтае эти компоненты сохранились и подверглись научному изучению далеко не в равной степени. Наибольшие успехи можно отметить в области изучения нематериального наследия: в XX - начале XXI века было проведено большое количество полевых экспедиций, собравших обширный фольклорно-этнографический материал. Как следствие, в музейно-туристической сфере в настоящее время работает большое количество специалистов в области исполнения этнической музыки, в том числе и старообрядческого фольклора.

Значительно сложнее обстоит дело с материальными компонентами наследия: так, например, до настоящего времени на Алтае почти не сохранился старообрядческий исторический культурный ландшафт, что является несомненной невосполнимой, даже катастрофической утратой. Коллективизация и сопутствующее ей уничтожение религиозных «пережитков» проводились здесь в особо жестких и беспощадных формах. В результате, к концу 1930-х гг. в регионе не осталось буквально ни одной зарегистрированной общины и ни одного, легально действующего старообрядческого храма или моленной. Закрытой оказалась и каменная Барнаульская Крестовоздвиженская церковь, крупнейшая на Алтае, построенная в 1908-1915 гг. в эклектическом стиле древнерусской храмовой архитектуры с элементами русского модерна, с оригинальной деревянной шатровой колокольней [3, с. 34]. Здание несколько десятилетий прослужило для административных нужд, и было взорвано в 1967 году при прокладке трамвайного полотна.

Культовые помещения алтайских старообрядцев, построенные в конце XIX - начале XX века, были у них отобраны и подверглись перепланировке, демонтажу, нецелевому использованию: чаще всего под сельские клубы и школы. В ряде случаев они оказались брошены без присмотра и постепенно разрушились, как это было, например, со строениями Белорецкого женского монастыря, закрытого зимой 1929/1930 гг. В настоящее время удается лишь, с той или иной степенью достоверности, установить их местонахождение. Культовое имущество, хранившееся в этих зданиях - книги, иконы и пр., было частью конфисковано и погибло, частью сохранено верующими, спрятавшими его в своих домах. Можно констатировать, что сакральный старообрядческий ландшафт практически не сохранился.

Не лучшим образом обстоит дело и в сфере музейной презентации движимых памятников. С одной стороны, можно констатировать некоторую исчерпанность возможностей вещевых сборов: на Алтае подавляющее большинство памятников старообрядческой культуры уже подверглось музеефикации, причем по большей части музеями Москвы, Санкт-Петербурга, Омска, то есть, находится в фондовых собраниях за пределами Алтайского края. С другой стороны, даже те памятники, которые имеются в музейных фондах Алтая, весьма непросто идентифицировать в общем массиве предметов русской традиционной культуры, за отсутствием или неявной выраженностью определяющих признаков, недостатком информации и пр. Эта работа требует от музейных 
специалистов не только высочайшего профессионализма, но и конкретной методической базы, которая пока отсутствует.

Как следствие, на Алтае - крупнейшем историческом центре сибирского старообрядчества, до настоящего времени не уделялось должного внимания продвижению культуры старообрядческих сообществ и целенаправленному формированию соответствующих тематических коллекций. Не наблюдается выделения таковых внутри уже имеющихся фондов краеведческих и прочих музеев, где памятники старообрядчества не атрибутируются и не презентуются как таковые. По существу они оказались растворены в общих коллекциях крестьянской материальной культуры одежды, утвари, инструментария, предметов культа. Отсутствуют грамотные музейные экспозиции старообрядческой культуры, исключая отдельные, не всегда удачные попытки небольших частных музеев специализироваться по этому профилю.

Таким образом, старообрядчество, его самобытная культура, его роль в истории России, весомый вклад в освоение Сибири и Алтая, популяризируются очень мало. Для использования этого ресурса необходимо сформировать на его основе соответствующий культурный продукт, приемлемый для включения в музейные и туристические экскурсии, экспозиции и другие учебные или познавательные презентационные формы.

Основная тенденция, определяющая цивилизационную самобытность старообрядчества как древнейшей ветви православного христианства, - его традиционная приверженность архаичным формам русской культуры. Памятники этой культуры, во всем ее локально-территориальном многообразии, представляют собой ценный компонент наследия конкретных регионов. Религиозная специфика и исторический опыт русского старообрядчества обусловили его принципиальный традиционализм - глубокую приверженность традиции как фактору, обеспечивавшему стабильность и воспроизводство его образа жизни в условиях гонений, миграций, социальной изоляции. Исследователи и наблюдатели XIX - начала XX вв. многократно отмечали культурную самобытность старообрядчества, выражавшуюся в изобилии архаичных элементов, восходящих к допетровской Руси и славянской древности: «Кто хочет изучать характерные черты великороссов, тот должен изучать их у старообрядцев» [4, с. 234]. Современная наука видит непреходящее значение наследия старообрядчества, прежде всего, в том, что оно представляет собой наиболее архаичный из ныне существующих исторический пласт русской культуры, со всеми, присущими традиционному обществу, ценностями и смыслами, уравновешивающими модернизацию современного общественного сознания.

В целом, приходится признать, что музеефикация старообрядческой культуры, понимаемая как преобразование историко-культурных и природных объектов в объекты музейного показа с целью максимального сохранения и выявления их историко-культурной, научной, художественной ценности [5], представляет определенные сложности. Основная проблема интерпретации старообрядческого историко-культурного наследия в музейном пространстве состоит в том, что оно пока еще должным образом не выявлено, не систематизировано и не идентифицировано исследовательским сообществом - краеведами, историками материальной культуры, культурологами, представителями музейной науки, специалистами в области наследия. Данное обстоятельство затрудняет адекватную презентацию старообрядческой культуры как значимого компонента наследия региона. Очевидно, что это наследие, в силу ряда причин, представляет ряд сложностей для интегрирования в культурные программы.

Тем не менее, выделить старообрядческое наследие в специальные тематические коллекции в музеях разного профиля и статуса представляется вполне возможным. Их могли бы составить предметы, бесспорно, или с большой степенью вероятности и при соответствующем обосновании, соотносимые со старообрядческой культурой. Сюда можно причислить элементы костюма, традиционного интерьерного текстиля, домовую и прялочную роспись, керамику, а также предметы культа: иконы старообрядческого письма, медную пластику; киоты, божницы, богослужебные книги и многое другое. В качестве вспомогательных материалов в процессе атрибуции следует использовать научную литературу, информацию, полученную от владельцев при полевых вещевых сборах, сведения о составе населения мест сборов, а также аналогии. В презентации 
данного материала можно основное внимание уделить сакральному наполнению материальных памятников, уводящему к культурным смыслам русского средневековья и дохристианской древности.

Перспективным направлением для музейной презентации старообрядческого наследия может стать их информационное наполнение, выраженное в нарративах, воспроизводящих представления об истории и культуре старообрядчества. Так, например, в музее истории и культуры Уймонской долины села Верхний Уймон Усть-Коксинского района Республики Алтай имеется уникальный опыт формирования на основе местного старообрядческого историко-этнографического и фольклорного материала - житейской истории, паремий, диалектизмов, духовных стихов, - качественного музейного продукта, предлагаемого в виде увлекательного письменного и устного повествования [6, с. 32-33].

Оптимальным учреждением для продвижения культуры старообрядчества может стать церковный музей, специализирующийся на данной теме. Примеры таких музеев в Сибири имеются, но их очень мало - не более 5-6, и это число пока не растет [7]. Возможности религиозного музея в данном направлении значительно шире, чем у музеев государственных, особенно в плане комплектования коллекций. В презентации старообрядческой культуры можно широко использовать этнографический материал, который позволяет продемонстрировать эту культуру не только в относительно целостном виде, но и в оригинальных трактовках, с выявлением новых, нетрадиционных аспектов. Ключевым моментом здесь может быть то обстоятельство, что многие артефакты русской этнокультуры несут на себе двойную религиозно-смысловую нагрузку: имея дохристианское происхождение, они были переосмыслены христианской культурой и стали ее неотъемлемыми компонентами, получив в ней новое значение.

В силу ряда причин эта двойственность хорошо просматривается в старообрядческом материальном комплексе, в частности таком знаковом его элементе, как одежда: хорошо известно, сколь серьезное значение придавалось старообрядцами внешнему облику человека. В выборе элементов традиционного костюма они отдавали предпочтение наиболее архаичным формам, особенно для одежды, надеваемой для совершения религиозных обрядов. Очевидно, что данный этнографический компонент может быть интерпретирован как важная конфессиональная характеристика, многое объясняющая не только в культуре, но и в религиозной психологии и ментальности старообрядчества.

Поскольку архаика присутствует в одеянии старообрядцев до сегодняшнего дня, постольку вещевые сборы в этой области значительно облегчены, по той причине, что хронология собираемых артефактов может быть сколь угодно продлена во времени. Возможно включение в музейные коллекции не только предметов недавнего происхождения, вышедших из употребления по своей изношенности или по другой причине, но и новоделов как таковых. Ввиду того, что музей по своему профилю не этнографический, а религиозный, для него ценны не только памятники, созданные и бытовавшие в сфере определенной этнокультуры, но и современные копии, достоверно их воспроизводящие.

В экспозиции религиозного музея важный раздел может быть сформирован из традиционного текстиля, использовавшегося в убранстве старообрядческих церквей и моленных: дорогих шалей, самотканых скатертей, салфеток, ковриков и другого этнографического материала. Можно видеть, что весь традиционный текстиль и предметы из него соотносимы, как со сферой традиционного быта, домашнего ремесла, а иногда и этнографического искусства, так и с предметной средой религиозной культуры.

Подводя итог сказанному, можно констатировать наличие большого культурного потенциала в наследии старообрядчества Алтая - самобытной этнокультурной общности, сыгравшей важную роль в начальном освоении его территории, равно как и с дальнейшей его историей. Культурноисторическое значение этого наследия заключается в его генетической связи со славянской и великорусской культурой средневековья, благодаря чему оно не только представляет собой зримую связь с историческими этапами, далеко отстоящими по времени, но и в значительной степени воспроизводит их в реалиях современности. 
В настоящее время это наследие заключается в материальных объектах, традициях религиозной и повседневно-бытовой культуры, а также памятниках фольклора и устной истории, значительная часть которых еще требует выявления и идентификации.

За прошедшее столетие значительный ущерб был нанесен старообрядческому культурному ландшафту, что во многом было связано с маргинализацией старообрядчества в условиях атеистической пропаганды советского периода. По этой же причине старообрядчество как культурная общность не было выделено в общем массиве русских крестьян Сибири, памятники его культуры не были сформированы в виде отдельных музейных коллекций. Вследствие указанных причин материальное наследие старообрядчества представляет собой музейный и внемузейный материал, который сложно поддается преобразованию в музейно-туристический культурный продукт. Напротив, памятники духовной культуры старообрядчества, как наиболее изученный компонент его наследия, наряду с его историей, в настоящий момент также достаточно хорошо разработанной, значительно легче включаются в различные презентационные формы, что доказывает имеющийся в данной области опыт.

Более глубокая музейная атрибуция, несомненно, позволит выявить, пусть поначалу небольшое в количественном отношении, собрание предметов старообрядческого материального комплекса, что не только даст возможность создания новых тематических экспозиционных блоков и выставок, но и представит материал для более глубокого изучения старообрядческого культурного наследия. Важным средством наполнения презентационных ресурсов может стать научно-музейная реконструкция недостающих, утраченных или недосягаемых памятников культуры.

Использование наследия в культурно-познавательных целях предполагает мобилизацию, наряду с материальными объектами, его информативного потенциала, поэтому одной лишь ревизии сохранившихся артефактов здесь явно недостаточно. Необходимо глубокое понимание смыслов и значений различных компонентов культуры, таких, как предметы религиозного и бытового назначения - архитектурные сооружения, одежда, утварь и др. Следовательно, демонстрация сохранившихся до нашего времени артефактов материальной культуры старообрядчества невозможна без их глубокого семиотического анализа, который позволил бы реконструировать особенности религиозного мировоззрения их создателей, а также выявить культурную модель, в рамках которой они были созданы. Данная задача стоит, прежде всего, перед музейной наукой, а также перед специалистами в области культурного наследия, теоретические наработки которых могут быть положены в основу презентации и популяризации старообрядческой культуры агентами туристического рынка.

Дальнейшая разработка проблемы, поставленной в настоящем исследовании, может быть направлена на выявление культурных маркеров конфессиональных общностей внутри старообрядческого мира, отнюдь не единого в религиозном отношении: как известно, старообрядчество распадается на множество церквей и их отдельных течений, порой радикально различающихся между собой. Кроме того, внутри старообрядческой общности существовало множество этнолокальных групп, также различающихся в культурном отношении, что хорошо просматривается в их материальном комплексе, в особенности в одежде. Исследование этих вопросов может вывести музейную атрибуцию на новый качественный уровень и, кроме того, несомненно, обеспечит более объемное информационное наполнение памятников культурного наследия старообрядчества.

\section{Список литературы}

1. Кочергина, М. В. Русское старообрядчество и сохранение культурного наследия Древней Руси: история и современность // Вестник Брянского государственного университета. - 2019. № 2. - С. 51-60.

2. Семилетникова, Е. С. История и культура старообрядчества Московской губернии как объект музейной презентации // Вопросы музеологии. - 2017. - № 1. - С. 32-38.

3. Дементьева, Л. С. Строительство храма во имя Воздвижения Креста Господня в Барнауле // Архитектура и строительство Сибири. - 2002. - № 4. - С. 32-35/ 
4. Гакстгаузен, Август фон. Исследования внутренних отношений народной жизни и в особенности сельских учреждений России. - Т. 1. - Москва : Тип. А. Н. Мамонтова и К을 1870 . - XXII, $490 \mathrm{c}$.

5. Музеефикация // Словарь музейных терминов Рос. музейной энциклопедии : [сайт]. Москва, 2002-2021. - URL: http://museum.ru/rme/mb_musf.asp (дата обращения: 22.06.2021).

6. Куприянова, И. В. Коммерциализация старообрядческого культурного наследия в туристическом кластере Уймонской долины // Учёные записки (Алтайская государственная академия культуры). - 2020. - № 22. - С. 29-34.

7. Полякова, Е. А. Музеи старообрядческой культуры как инструмент национальной безопасности России (на примере музея истории старообрядчества Сибири) // Учёные записки (Алтайская государственная академия культуры). - 2019. - № 3. - С. 14-19.

Irina V. Kupriianova, Doctor of Historical Sciences, Associate Professor Altai State Institute of Culture (Barnaul, Russia) irinak-63@mail.ru

\title{
PROBLEMS OF MUSEUM PRESERVATION OF OLD BELIEVERS' CULTURE IN ALTAI REGION, RUSSIA
}

\begin{abstract}
The paper considers perspectives of integration of the Russian Altai's Old Believers' historical and cultural heritage into the today's museum space of the area. The author names structural elements of Old Believers' heritage, makes an estimate of its preservation and exploration degree. Also, the article analysis a serious problem of attribution of Old Believers' heritage items, an issue of its integration into current museum and touristic programs. A key directions of elaboration of Old Believers' heritage, on the author's view, are uncovering and rethinking its information content, engaging oral, historical, folklore, ethnographic sources to offset deficit of real artifacts.

Keywords: Old Belief, historical and cultural heritage, Altai's Old Believers' historical and cultural heritage, semiotic discourse, a museum product, cultural landscape, tourism.
\end{abstract}

УДК 39(=161.1+=512.1)(571.15):001.891“1801/1925”,

DOI: $10.32340 / 2414-9101-2021-2-12-17$

А. В. Богочанова

Государственный художественный музей Алтайского края (Барнаул, Россия) bogochanoff@mail.ru

\section{ЭТНОГРАФИЧЕСКИЕ ИССЛЕДОВАНИЯ В ОБЩЕСТВЕННОМ КРАЕВЕДЕНИИ АЛТАЯ (ХІХ - НАЧАЛО ХХ В.)}

Аннотация. На примере этнографических исследований территории Алтая показан процесс накопления первоначального эмпирического материала, преимущественно силами представителей местного краеведческого движения, что обусловило общественный характер данного направления научной деятельности, сделавшего большой вклад в обеспечение отечественной науки этнографическими фактами как источниками, необходимыми для теоретического анализа. Рассмотрены методы, проблематика этнографических исследований, а также их связь с задачами общественного и государственного развития, определившая логику научного поиска. Показан вклад отдельных исследователей в формирование этнокультурного наследия Алтая, проанализирована научная и гуманитарная ценность данного явления. 